Article

\title{
Performance of Cr-doped vanadia/titania catalysts for low-temperature selective catalytic reduction of $\mathrm{NO}_{x}$ with $\mathrm{NH}_{3}$
}

\author{
Rui Yang a, Haifeng Huang a,*, Yijie Chen a , Xixiong Zhang a, Hanfeng Lu b,\# \\ a College of Biological and Environmental Engineering, Zhejiang University of Technology, Hangzhou 310014, Zhejiang, China \\ ${ }^{\mathrm{b}}$ Institute of Catalytic Reaction Engineering, College of Chemical Engineering, Zhejiang University of Technology, Hangzhou 310014, Zhejiang, China
}

\section{A R T I C L E I N F O}

\section{Article history:}

Received 4 March 2015

Accepted 6 May 2015

Published 20 August 2015

\section{Keywords:}

Low temperature

Selective catalytic reduction

Ammonia

Vanadia/titania catalyst

Nitrogen oxide removing

Sulfur resistance

Chromium doping

\begin{abstract}
A B S T R A C T
$\mathrm{Cr}-\mathrm{V} / \mathrm{TiO}_{2}$ catalysts with different $\mathrm{Cr} / \mathrm{V}$ molar ratios for low-temperature selective catalytic reduction (SCR) of $\mathrm{NO}$ with $\mathrm{NH}_{3}$ were prepared by impregnation. The samples were characterized using $\mathrm{X}$-ray diffraction, $\mathrm{NH}_{3}$ temperature-programmed desorption, $\mathrm{H}_{2}$ temperature-programmed reduction, and X-ray photoelectron spectroscopy. The results show that doping with $\mathrm{Cr}$ ions increased the amounts of weak and medium acid sites on the catalyst surface, as well as the low-temperature reductive capacity for high-valence $\mathrm{V}$ ions, and promoted the chemical adsorption of oxygen on the catalyst surface, which enhanced the rate of the SCR reaction. The catalyst with a $\mathrm{Cr} / \mathrm{V}$ molar ratio of 0.2:0.8 and $10 \mathrm{wt} \%$ loading gave the largest amount of weak acid sites and the best $\mathrm{NO}_{x}$-removing performance, with a $\mathrm{NO}_{x}$ conversion greater than $90 \%$ at $160-300{ }^{\circ} \mathrm{C}$. This catalyst had high stability in the presence of $0.01 \% \mathrm{SO}_{2}$.
\end{abstract}

(c) 2015, Dalian Institute of Chemical Physics, Chinese Academy of Sciences. Published by Elsevier B.V. All rights reserved.

\section{Introduction}

Nitrogen oxides $\left(\mathrm{NO}_{x}\right)$ emitted from thermal power plants and automobile exhaust gases are major air pollutants. The selective catalytic reduction (SCR) of $\mathrm{NO}_{x}$ with $\mathrm{NH}_{3}$ is the most effective technology for $\mathrm{NO}_{x}$ abatement [1-3]. Currently, $\mathrm{V}_{2} \mathrm{O}_{5}-\mathrm{WO}_{3} / \mathrm{TiO}_{2}$ and $\mathrm{V}_{2} \mathrm{O}_{5}-\mathrm{MoO}_{3} / \mathrm{TiO}_{2}$ are the most widely used catalysts, in a narrow temperature window of $300-400{ }^{\circ} \mathrm{C}$ [4]. Most SCR systems are installed behind an economizer that allows the flue gas temperature to exceed $300{ }^{\circ} \mathrm{C}$ to maintain high catalytic activity. However, the catalyst life is short because it is easily affected by high concentrations of flue dust, $\mathrm{SO}_{2}$, alkali metals, and other factors. In addition, blockage by $\left(\mathrm{NH}_{4}\right)_{2} \mathrm{SO}_{4}$ byproducts during high-temperature processes is a problem that needs to be addressed. The preferred technique is to locate the SCR $\mathrm{NO}_{x}$-removing $\left(\mathrm{DeNO}_{x}\right)$ unit after the desulfurization equipment in coal-fired power plants [5]. In this process, the flue gas temperature can drop to $250{ }^{\circ} \mathrm{C}$ below, at which V-based catalysts do not maintain high $\mathrm{NO}_{x}$ conversions [6].

Recent studies suggest that V catalysts have excellent sulfur resistance [7]. Various methods such as use of additives or different supports, e.g., $\mathrm{Sb}-\mathrm{V}_{2} \mathrm{O}_{5} / \mathrm{TiO}_{2}$ [8], $\mathrm{V}_{2} \mathrm{O}_{5}-\mathrm{CeO}_{2} / \mathrm{TiO}_{2}$ [9], $\mathrm{V}_{2} \mathrm{O}_{5}-\mathrm{WO}_{3} / \mathrm{Ti}-\mathrm{Si}$ [10], $\mathrm{V}_{2} \mathrm{O}_{5} / \mathrm{CeO}_{2}-\mathrm{ZrO}_{2}$ [11], and $\mathrm{V}_{2} \mathrm{O}_{5} / \mathrm{AC}$ [12] catalysts, have been used to further enhance the low-temperature activities of $\mathrm{V}$ catalysts at low temperatures and maintain their high sulfur resistance. The low-temperature activities of these catalysts were improved, but the sulfur resistance of $\mathrm{V}_{2} \mathrm{O}_{5}$

\footnotetext{
* Corresponding author. Tel/Fax: +86-571-88320385; E-mail: hhf66@zjut.edu.cn

\# Corresponding author. Tel/Fax: +86-571-88320767; E-mail: luhf@zjut.edu.cn

This work was supported by the National Natural Science Foundation of China (21107096), the Zhejiang Provincial Natural Science Foundation of China (LY14E080008), and the Commission of Science and Technology of Zhejiang Province (2013C03021).

DOI: 10.1016/S1872-2067(15)60884-1 | http://www.sciencedirect.com/science/journal/18722067 | Chin. J. Catal., Vol. 36, No. 8, August 2015
} 
decreased.

Improvements in $\mathrm{V}$ catalyst activities at low temperatures and maintenance of the sulfur resistance of efficient additive-containing catalysts are particularly important. It has been reported that the low-temperature activity of a $\mathrm{Cr}_{2} \mathrm{O}_{3} / \mathrm{TiO}_{2}$ catalyst was high because more acid sites were present on the surface [13]. Thirupathi et al. [14] obtained 90\% $\mathrm{NO}_{x}$ conversion at $180{ }^{\circ} \mathrm{C}$ using $\mathrm{CrO}_{x}$-doped $\mathrm{MnO}_{x} / \mathrm{TiO}_{2}$; catalyst characterizations showed that surface acidity (Brønsted and Lewis acid sites) had significantly increased. Tong et al. [15] reported that the conversion of NO reached $80.7 \%$ at $330{ }^{\circ} \mathrm{C}$ for a $\mathrm{Cr}-\mathrm{Ce} / \mathrm{TiO}_{2}$ catalyst, but dropped from $80.7 \%$ to $62.4 \%$ after $10 \mathrm{~h}$ of sulfur resistance test. Chen et al. [16] prepared $\mathrm{Cr}-\mathrm{Mn}$ catalysts using the citric acid method; the catalytic activity reached $98.5 \%$ at $120{ }^{\circ} \mathrm{C}$ but decreased to about $20 \%$ after $5 \mathrm{~h}$ of sulfur resistance test. Chromium oxide has good low-temperature activity, but its sulfur resistance needs to be improved.

In this study, $\mathrm{Cr}-\mathrm{V}-\mathrm{O} / \mathrm{TiO}_{2}$ catalysts were prepared using $\mathrm{Cr}$ and $\mathrm{V}$ as the active components and $\mathrm{TiO}_{2}$ as the carrier. The influence of the $\mathrm{Cr} / \mathrm{V}$ molar ratio and loading was investigated, the catalysts were characterized, and the catalytic mechanism was investigated.

\section{Experimental}

\subsection{Catalyst preparation}

Certain amounts of ammonium metavanadate (AR) and chromium nitrate (AR) were dissolved in deionized water. The solution was adequately stirred in a water bath at $60{ }^{\circ} \mathrm{C}$ and mixed with $\mathrm{TiO}_{2}$ powders by magnetic stirring for $20 \mathrm{~min}$. Moisture was removed at $60{ }^{\circ} \mathrm{C}$ using a rotary vacuum evaporator. The resulting materials were dried at $110{ }^{\circ} \mathrm{C}$ overnight and calcined at $450{ }^{\circ} \mathrm{C}$ for $3 \mathrm{~h}$. The samples were compressed into tablets and crushed to 20-30 mesh. $\mathrm{CrO}_{x} / \mathrm{TiO}_{2}$ and $\mathrm{VO}_{x} / \mathrm{TiO}_{2}$ catalysts were prepared using the same method. The $\mathrm{Cr}-\mathrm{V} / \mathrm{TiO}_{2}$ catalysts with different $\mathrm{Cr} / \mathrm{V}$ molar ratios were denoted by $\mathrm{Cr}_{x}-\mathrm{V}_{1-x} / \mathrm{TiO}_{2}(x=0.7,0.5,0.3,0.2,0.1)$ and $\mathrm{Cr}_{0.2}-\mathrm{V}_{0.8} / \mathrm{TiO}_{2}$ catalysts with different weight percentage loadings were denoted by $a$ wt $\% \mathrm{Cr}_{0.2}-\mathrm{V}_{0.8} / \mathrm{TiO}_{2}(a=5,10,20,50)$.

\subsection{Catalyst characterization}

Powder X-ray diffraction (XRD) patterns were obtained using a SCINTAG XTRA diffractometer (Ni-filtered $\mathrm{Cu} K_{\alpha}$ radiation) operated at $40 \mathrm{kV}$ and $50 \mathrm{~mA}$. Intensity data were recorded in the $2 \theta$ range from $10^{\circ}$ to $80^{\circ}$, with a step size of $0.04^{\circ}$.

$\mathrm{X}$-ray photoelectron spectroscopy (XPS) was performed using an ESCALab 220i-XL electron spectrometer (VG Scientific Company) with $300 \mathrm{~W} \mathrm{Al} K_{\alpha}$ radiation. The pressure was maintained at $3 \times 10^{-9}$ mbar. The $\mathrm{C} 1 s$ line at $284.6 \mathrm{eV}$ from carbon was used as a reference, and the binding energies were calculated with respect to this line.

$\mathrm{H}_{2}$ temperature-programmed reduction $\left(\mathrm{H}_{2}-\mathrm{TPR}\right)$ and $\mathrm{NH}_{3}$ temperature-programmed desorption ( $\mathrm{NH}_{3}$-TPD) were performed using a Micromeritics Auto Chem FINE SORB-3010E chemisorption analyzer. Prior to $\mathrm{H}_{2}$-TPR analysis, the samples (200 mg) were treated with $\operatorname{Ar}\left(30 \mathrm{~mL} / \mathrm{min}\right.$ at $150{ }^{\circ} \mathrm{C}$ for 30 min, cooled to $80^{\circ} \mathrm{C}$, and flushed for $10 \mathrm{~min}$ ). The atmosphere was changed to $5 \% \mathrm{H}_{2} / \mathrm{Ar}(30 \mathrm{~mL} / \mathrm{min})$, and the reactor temperature was increased to $750{ }^{\circ} \mathrm{C}$. For $\mathrm{NH}_{3}$-TPD, the samples (150 mg) were heated in a pure He flow at $400{ }^{\circ} \mathrm{C}$ for $1 \mathrm{~h}$, and cooled to $100{ }^{\circ} \mathrm{C}$ in a He atmosphere. The samples were treated with anhydrous $\mathrm{NH}_{3}$ for $1 \mathrm{~h}$ and then purged with He for $1 \mathrm{~h}$. The temperature was increased linearly at a rate of $10{ }^{\circ} \mathrm{C} / \mathrm{min}$, and TPD was performed in pure He over the temperature range $100-900{ }^{\circ} \mathrm{C}$.

\subsection{Catalytic activity tests}

The SCR activity was measured in a fixed-bed quartz reactor containing $0.5 \mathrm{~g}$ of catalyst mixed with $0.5 \mathrm{~g}$ of quartz sand, with a gas hourly space velocity (GHSV) of $60000 \mathrm{~mL} /(\mathrm{h} \cdot \mathrm{g})$. The simulated flue gas composition was as follows: $\varphi$ (NO) = $\varphi\left(\mathrm{NH}_{3}\right)=0.05 \%, \varphi\left(\mathrm{O}_{2}\right)=5 \%, \varphi\left(\mathrm{SO}_{2}\right)=0.01 \%$ (as needed), $\varphi$ (water) $=10 \mathrm{vol} \%$ (as needed), and balance $\mathrm{N}_{2}$. The total flow rate was $500 \mathrm{~mL} / \mathrm{min}$. The concentrations of $\mathrm{NO}, \mathrm{NO}_{2}, \mathrm{O}_{2}$, and $\mathrm{SO}_{2}$ were monitored continuously using a TESTO350-XL gas analyzer. To ensure stability and accuracy of the data, the data were recorded after 20 min when each test condition was changed.

\section{Results and discussion}

\subsection{XRD analysis}

The effects of Cr doping on the bulk structures of the catalysts were investigated using XRD. Fig. 1 shows the XRD patterns of the catalysts. It shows that all the peaks in the patterns were attributable to the anatase phase of $\mathrm{TiO}_{2}$. No diffraction peaks attributed to $\mathrm{Cr}$ and $\mathrm{V}$ species were observed, suggesting that the low-loaded active phase was highly dispersed on the $\mathrm{TiO}_{2}$ support and had an amorphous or microcrystalline structure.

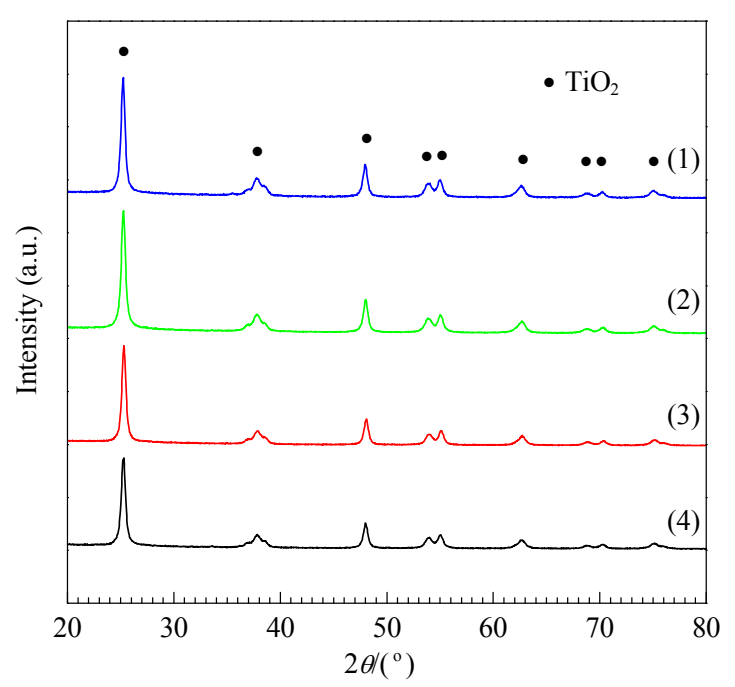

Fig. 1. XRD patterns of catalysts. (1) $\mathrm{TiO}_{2}$; (2) $\mathrm{VO}_{x} / \mathrm{TiO}_{2}$; (3) $\mathrm{Cr}_{0.2}-\mathrm{V}_{0.8} / \mathrm{TiO}_{2}$; (4) $\mathrm{Cr}_{x} / \mathrm{TiO}_{2}$. 


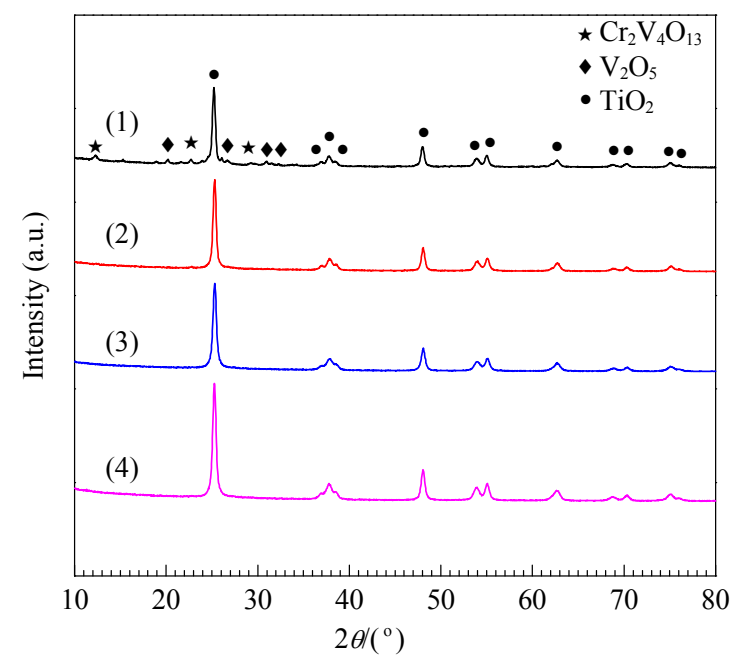

Fig. 2. XRD patterns of $\mathrm{Cr}_{0.2}-\mathrm{V}_{0.8} / \mathrm{TiO}_{2}$ catalysts with different loadings. (1) $50 \mathrm{wt} \%$; (2) $20 \mathrm{wt} \%$; (3) $10 \mathrm{wt} \%$; (4) $5 \mathrm{wt} \%$.

The effect of loading on the catalyst bulk was determined by examining $\mathrm{Cr}_{0.2}-\mathrm{V}_{0.8} / \mathrm{TiO}_{2}$ catalysts with different loadings. Fig. 2 shows that the composite was highly dispersed on the surface of the $\mathrm{TiO}_{2}$ support for active component loadings less than 20 wt $\%$. The composite state phase $\left(\mathrm{Cr}_{2} \mathrm{~V}_{4} \mathrm{O}_{13}\right)$ was observed on the $\mathrm{Cr}_{0.2}-\mathrm{V}_{0.8} / \mathrm{TiO}_{2}$ catalyst surface when the loading was 20 $w \mathrm{t} \%$. When the loading was increased to $50 \mathrm{wt} \%$, the diffraction peaks of the active component became more apparent.

\section{2. $\mathrm{NH}_{3}-\mathrm{TPD}$ analysis}

The surface areas and types of acid sites, determined using $\mathrm{NH}_{3}$-TPD, for catalysts with various $\mathrm{Cr} / \mathrm{V}$ molar ratios are summarized in Table 1.

$\mathrm{NH}_{3}$-TPD experiments were performed to determine the acid site distributions on the prepared catalysts. The $\mathrm{NH}_{3}$-TPD curves are shown in Fig. 3. The peak centered at about $200{ }^{\circ} \mathrm{C}$ is caused by $\mathrm{NH}_{3}$ desorption from weak acid sites, and that centered at about $400{ }^{\circ} \mathrm{C}$ is attributed to desorption from medium and strong acid sites. The peak above $400^{\circ} \mathrm{C}$ is attributed to $\mathrm{NH}_{3}$ desorption from strong acid sites. Fig. 3 shows that the desorption peak of the $\mathrm{VO}_{x} / \mathrm{TiO}_{2}$ catalyst in the range $150-350{ }^{\circ} \mathrm{C}$ arises from $\mathrm{NH}_{3}$ desorption from weak and medium acid sites distributed on the catalyst surface. Addition of $\mathrm{Cr}$

Table 1

Types of acid sites and surface areas for catalysts with various $\mathrm{Cr} / \mathrm{V}$ molar ratios determined using $\mathrm{NH}_{3}$-TPD.

\begin{tabular}{lccccc}
\hline \multirow{2}{*}{ Catalyst } & \multicolumn{4}{c}{ Acid site distribution ${ }^{\mathrm{a}}$} & \begin{tabular}{c}
$A_{\text {BET }}$ \\
\cline { 2 - 5 }
\end{tabular} \\
\cline { 2 - 5 } & Weak & Medium & Strong & Total & \\
\hline $\mathrm{VO}_{x} / \mathrm{TiO}_{2}$ & 0.10 & 0.26 & - & 0.36 & 56.8 \\
$\mathrm{Cr}_{0.1}-\mathrm{V}_{0.9} / \mathrm{TiO}_{2}$ & 0.13 & 0.34 & - & 0.47 & 53.7 \\
$\mathrm{Cr}_{0.2}-\mathrm{V}_{0.8} / \mathrm{TiO}_{2}$ & 0.12 & 0.39 & - & 0.51 & 56.2 \\
$\mathrm{Cr}_{0.3}-\mathrm{V}_{0.7} / \mathrm{TiO}_{2}$ & 0.13 & 0.11 & 0.44 & 0.68 & 54.7 \\
$\mathrm{Cr}_{0.5}-\mathrm{V}_{0.5} / \mathrm{TiO}_{2}$ & 0.14 & 0.26 & 0.52 & 0.92 & 52.4 \\
$\mathrm{Cr}_{0.7}-\mathrm{V}_{0.3} / \mathrm{TiO}_{2}$ & 0.11 & 0.30 & 0.58 & 1.00 & 56.2 \\
$\mathrm{CrO}_{x} / \mathrm{TiO}_{2}$ & 0.05 & 0.30 & 0.59 & 0.94 & 83.0 \\
\hline
\end{tabular}

a The amount of acidity of $\mathrm{Cr}_{0.7}-\mathrm{V}_{0.3} / \mathrm{TiO}_{2}$ was assigned as 1.0 and compared with the other samples.

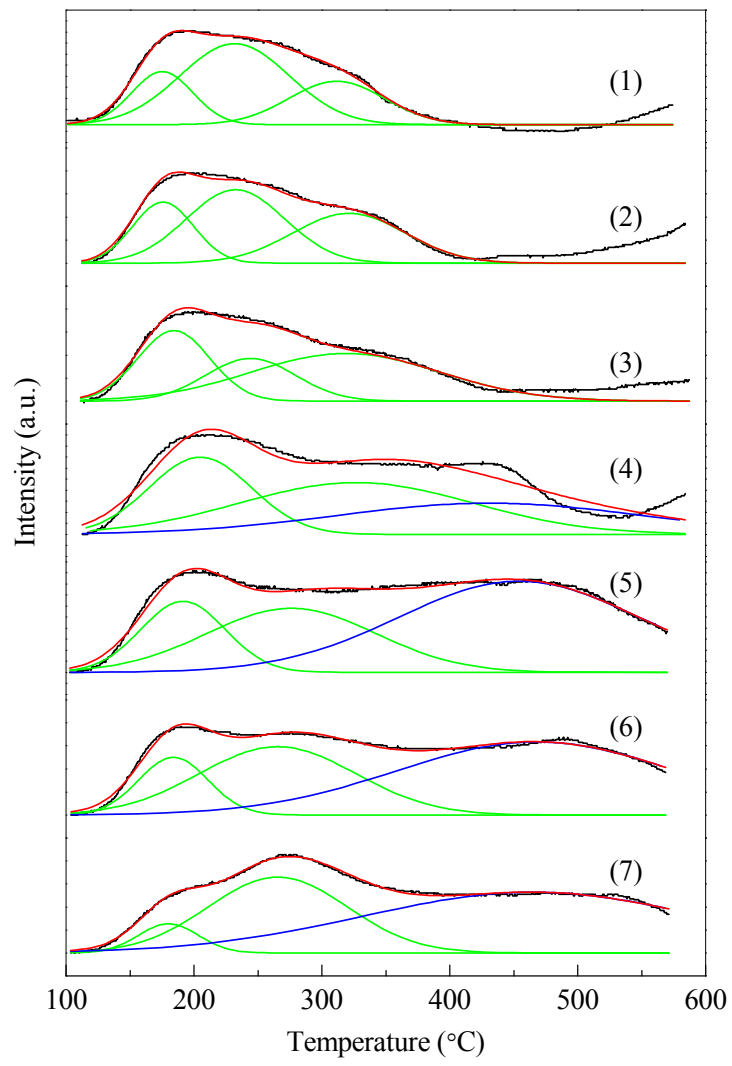

Fig. 3. $\mathrm{NH}_{3}$-TPD curves for catalysts with various $\mathrm{Cr} / \mathrm{V}$ molar ratios. (1) $\mathrm{VO}_{x} / \mathrm{TiO}_{2}$; (2) $\mathrm{Cr}_{0.1}-\mathrm{V}_{0.9} / \mathrm{TiO}_{2}$; (3) $\mathrm{Cr}_{0.2}-\mathrm{V}_{0.8} / \mathrm{TiO}_{2}$; (4) $\mathrm{Cr}_{0.3}-\mathrm{V}_{0.7} / \mathrm{TiO}_{2}$; (5) $\mathrm{Cr}_{0.5}-\mathrm{V}_{0.5} / \mathrm{TiO}_{2}$; (6) $\mathrm{Cr}_{0.7}-\mathrm{V}_{0.3} / \mathrm{TiO}_{2} ;(7) \mathrm{CrO}_{x} / \mathrm{TiO}_{2}$.

caused broadening of the desorption peak and the amount of chemisorbed $\mathrm{NH}_{3}$ increased. These results suggest that the addition of $\mathrm{Cr}$ significantly enhanced the concentration and acidity of acid sites [17]. The desorption peak of the $\mathrm{Cr}_{0.2}-\mathrm{V}_{0.8} / \mathrm{TiO}_{2}$ catalyst appeared in the range $160-300{ }^{\circ} \mathrm{C}$; this catalyst had the largest amounts of weak and medium acid sites on its surface. When the $\mathrm{Cr} / \mathrm{V}$ molar ratio was greater than $0.2: 0.8$, the $\mathrm{NH}_{3}$ desorption peak in the range $450-550{ }^{\circ} \mathrm{C}$ was strong. This finding indicates the presence of a large number of strong acid sites on the surfaces of these catalysts; this is not conducive to desorption of $\mathrm{NH}_{3}$ and is unfavorable for SCR activity. The optimum amount of $\mathrm{Cr}$ on the V-based catalyst surface would give the highest amount of weak acid sites and the lowest amount of strong acid sites.

\section{3. $\mathrm{H}_{2}$-TPR analysis}

$\mathrm{H}_{2}$-TPR was used to investigate the catalyst reducibility; the results are shown in Fig. 4 . The peak at $470{ }^{\circ} \mathrm{C}$ for the $\mathrm{VO}_{x} / \mathrm{TiO}_{2}$ catalyst can be assigned to the reduction of $\mathrm{V}^{5+}$ to $\mathrm{V}^{3+}$ [18]. The peak observed above $625^{\circ} \mathrm{C}$ is ascribed to unsupported $\mathrm{V}_{2} \mathrm{O}_{5}$, and could arise from uneven distribution of $\mathrm{V}$ on the $\mathrm{TiO}_{2}$ support. The reduction peak of the catalyst shifted to lower temperatures as the amount of chromium oxide increased. When the $\mathrm{Cr} / \mathrm{V}$ molar ratio was 0.2:0.8, the reduction temperature of $\mathrm{V}^{5+}$ dropped to $460{ }^{\circ} \mathrm{C}$, and no $\mathrm{Cr}$ reduction peak was observed. These results indicate good dispersion of $\mathrm{Cr}$ species on the cat- 


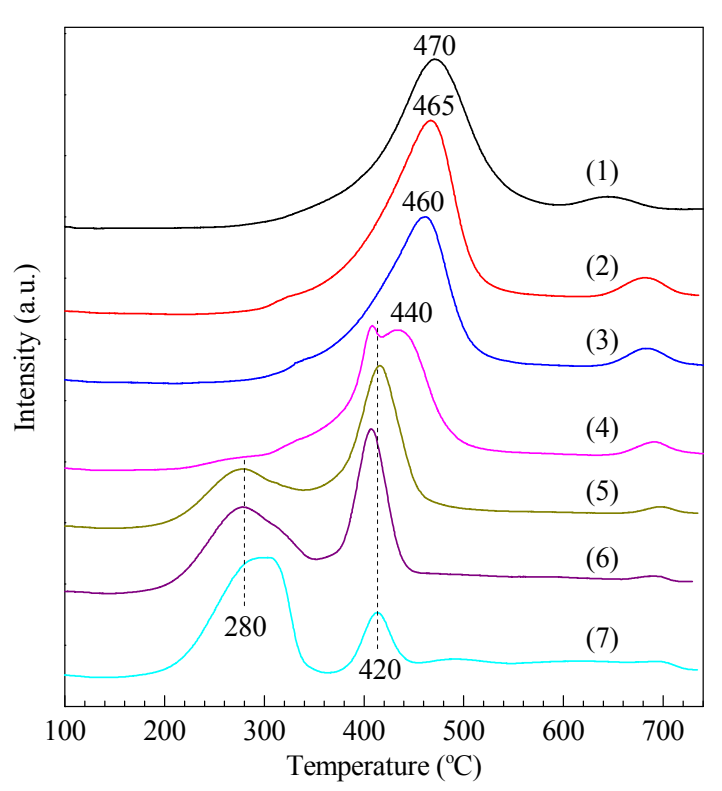

Fig. 4. $\mathrm{H}_{2}$-TPR curves of catalyst with various $\mathrm{Cr} / \mathrm{V}$ molar ratios. (1) $\mathrm{VO}_{x} / \mathrm{TiO}_{2}$; (2) $\mathrm{Cr}_{0.1}-\mathrm{V}_{0.9} / \mathrm{TiO}_{2}$; (3) $\mathrm{Cr}_{0.2}-\mathrm{V}_{0.8} / \mathrm{TiO}_{2}$; (4) $\mathrm{Cr}_{0.3}-\mathrm{V}_{0.7} / \mathrm{TiO}_{2}$; (5) $\mathrm{Cr}_{0.5}-\mathrm{V}_{0.5} / \mathrm{TiO}_{2}$; (6) $\mathrm{Cr}_{0.7}-\mathrm{V}_{0.3} / \mathrm{TiO}_{2}$; (7) $\mathrm{CrO}_{x} / \mathrm{TiO}_{2}$.

alyst surface. A combination of these results with those of the catalyst textural analysis suggests that interactions occurred between the phases (amorphous chromium oxides and vanadium oxides). These interactions could promote the reduction of $\mathrm{V}^{5+}$, which promoted the reaction. When the $\mathrm{Cr} / \mathrm{V}$ molar ratio was higher than 0.2:0.8, the reduction peak of $\mathrm{Cr}$ species was observed. The $\mathrm{CrO}_{x}$ TPR profile reported in the literature [14] showed two reduction peaks, at 280 and $420^{\circ} \mathrm{C}$; these could be attributed to reduction of $\mathrm{Cr}^{6+}$ to $\mathrm{Cr}^{5+}$ and of $\mathrm{Cr}^{5+}$ to $\mathrm{Cr}^{3+}$, respectively. The results show that the reduction peak of $\mathrm{V}$ weakened. Excess Cr therefore occupied the sites of $\mathrm{V}$ species, possibly preventing the SCR reaction.

\subsection{XPS analysis}

XPS was performed to investigate the surface binding energies and valence states of various catalyst species. The results are shown in Table 2 and Fig. 5. As shown in Fig. 5(a), the $01 s$ photoelectron spectra of the catalysts indicated the presence of two main types of oxygen, namely lattice oxygen $\left(\mathrm{O}_{\alpha}\right)$, with a binding energy of 529.0-530.0 eV, and surface oxygen $\left(\mathrm{O}_{\beta}\right)$, with a binding energy of 530.0-531.0 eV [19]. The proportions of surface oxygen in the Cr-doped catalysts were higher than that in the undoped catalyst (Table 2). This finding indicates that the Cr-doped catalyst had a higher proportion of oxygen vacancies than the undoped catalyst. The presence of surface oxygen improves the catalytic activity in the SCR reaction. This effect is an important reason for the increased catalytic activities of the Cr-doped catalysts [20].

The V $2 p$ XPS spectra of the catalyst samples are shown in Fig. 5(b). The peaks at 517.5 and $516.5 \mathrm{eV}$ can be ascribed to the $2 p_{3 / 2}$ binding energies of $\mathrm{V}^{5+}$ and $\mathrm{V}^{4+}$ [21]. The surface atomic ratios of $\mathrm{V}^{4+}$ to $\mathrm{V}^{5+}$ are listed in Table 2; these were obtained by deconvolution. The $10 \mathrm{wt} \% \mathrm{Cr}_{0.2}-\mathrm{V}_{0.8} / \mathrm{TiO}_{2}$ catalyst had the highest $\mathrm{V}^{4+} / \mathrm{V}^{5+}$ ratio, and the ratio decreased in the

Table 2

Binding energies and surface atomic concentrations of $\mathrm{O}, \mathrm{Cr}$, and $\mathrm{V}$ for the prepared catalysts determined from deconvoluted XPS spectra.

\begin{tabular}{|c|c|c|c|c|c|c|c|c|c|}
\hline \multirow{2}{*}{ Catalyst } & \multicolumn{3}{|c|}{ Binding energy $(\mathrm{eV})$} & \multicolumn{3}{|c|}{ Atomic concentration (\%) } & \multirow{2}{*}{$\mathrm{V}^{4+} / \mathrm{V}^{5+}$} & \multirow{2}{*}{$\mathrm{Cr}^{3+} / \mathrm{Cr}^{6+}$} & \multirow{2}{*}{$\mathrm{O}_{\beta} / \mathrm{O}_{\alpha}$} \\
\hline & $01 s$ & $\mathrm{~V} 2 p$ & $\operatorname{Cr} 2 p$ & 0 & $\mathrm{Ti}(\mathrm{Cr})^{*}$ & $\mathrm{~V}$ & & & \\
\hline $10 \mathrm{wt} \% \mathrm{VO}_{x} / \mathrm{TiO}_{2}$ & $530.02,531.30$ & $516.88,517.57$ & - & 68.33 & 25.70 & 5.97 & 0.59 & - & 0.61 \\
\hline 5 wt $\% \mathrm{Cr}_{0.2}-\mathrm{V}_{0.8} / \mathrm{TiO}_{2}$ & $529.98,531.17$ & $516.61,517.26$ & $577.42,580.05$ & 70.75 & 26.86 & 2.39 & 0.21 & 0.80 & 0.92 \\
\hline $10 \mathrm{wt} \% \mathrm{Cr}_{0.2}-\mathrm{V}_{0.8} / \mathrm{TiO}_{2}$ & $529.80,530.63$ & $516.88,517.59$ & $577.31,579.78$ & 68.06 & 26.91 & 5.03 & 0.73 & 0.97 & 1.00 \\
\hline $20 \mathrm{wt} \% \mathrm{Cr}_{0.2}-\mathrm{V}_{0.8} / \mathrm{TiO}_{2}$ & $529.82,530.35$ & $516.75,517.42$ & $576.93,579.10$ & 70.86 & 21.97 & 7.17 & 0.48 & 0.88 & 0.95 \\
\hline
\end{tabular}
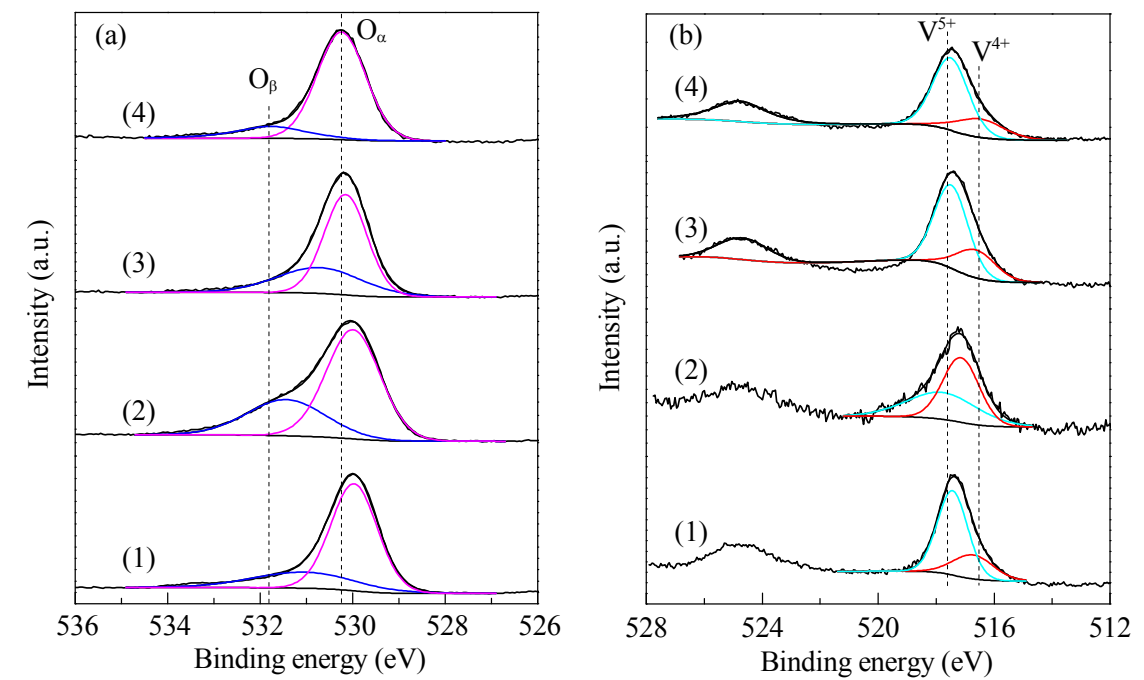

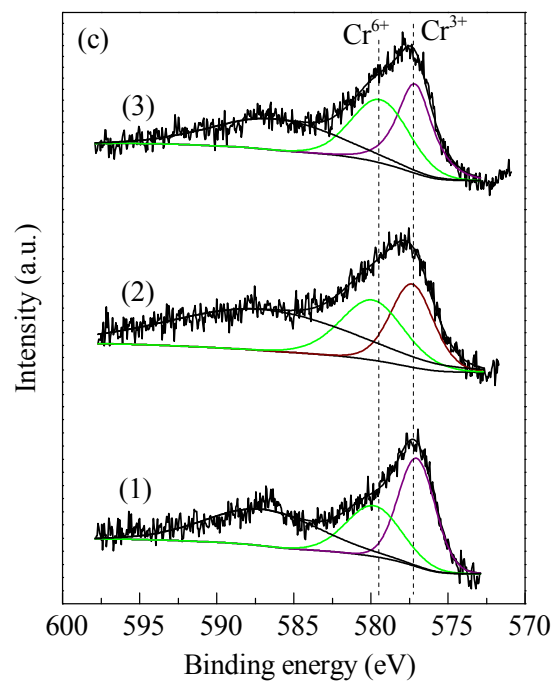

Fig. 5. XPS spectra of $\mathrm{O} 1 \mathrm{~s}$ (a), $\mathrm{V} 2 p$ (b), and $\mathrm{Cr} 2 p$ (c) of various catalysts. (1) $20 \mathrm{wt} \% \mathrm{Cr}_{0.2}-\mathrm{V}_{0.8} / \mathrm{TiO}_{2}$; (2) $5 \mathrm{wt} \% \mathrm{Cr}_{0.2}-\mathrm{V}_{0.8} / \mathrm{TiO}_{2}$; (3) 10 wt $\%$ $\mathrm{Cr}_{0.2}-\mathrm{V}_{0.8} / \mathrm{TiO}_{2} ;(4) \mathrm{VO}_{x} / \mathrm{TiO}_{2}$. 
order $10 \mathrm{wt} \% \mathrm{Cr}_{0.2}-\mathrm{V}_{0.8} / \mathrm{TiO}_{2}>10 \mathrm{wt} \% \mathrm{VO}_{x} / \mathrm{TiO}_{2}>20 \mathrm{wt} \%$ $\mathrm{Cr}_{0.2}-\mathrm{V}_{0.8} / \mathrm{TiO}_{2}>5 \mathrm{wt} \% \mathrm{Cr}_{0.2}-\mathrm{V}_{0.8} / \mathrm{TiO}_{2}$. A large $\mathrm{V}^{4+} / \mathrm{V}^{5+}$ ratio would generate more free electrons, which are formed from non-stoichiometric $\mathrm{V}$ ions in various valence-state-conversion processes.

Fig. 5(c) shows the XPS spectra of $\mathrm{Cr} 2 p$ on the catalyst surfaces. The $\mathrm{Cr}$ atoms on the catalyst surfaces had two valences $\left(\mathrm{Cr}^{6+}\right.$ and $\left.\mathrm{Cr}^{4+}\right)$. The data in Table 2 clearly show that the $\mathrm{Cr}-\mathrm{V}$ loading on the catalyst had little effect on the $\mathrm{Cr}^{3+} / \mathrm{Cr}^{6+}$ molar ratio.

\subsection{Catalyst performance}

The $\mathrm{NO}_{x}$ conversions over catalysts with various $\mathrm{Cr} / \mathrm{V}$ molar ratios as a function of reaction temperature are shown in Fig. 6. $\mathrm{VO}_{x} / \mathrm{TiO}_{2}$ and $\mathrm{CrO}_{x} / \mathrm{TiO}_{2}$ had poor activities at low temperatures, and $\mathrm{CrO}_{x} / \mathrm{TiO}_{2}$ had a narrow temperature window. The results show that small variations in the amount of $\mathrm{Cr}$ in the $\mathrm{Cr}-\mathrm{V} / \mathrm{TiO}_{2}$ catalysts influenced $\mathrm{NO}_{x}$ conversion. The curves for $\mathrm{Cr}_{0.1}-\mathrm{V}_{0.9} / \mathrm{TiO}_{2}$ and $\mathrm{Cr}_{0.2}-\mathrm{V}_{0.8} / \mathrm{TiO}_{2}$ show that the catalytic activities were significantly improved at low temperatures with increasing $\mathrm{Cr}$ content because this enhanced the weak acidity of the SCR catalyst. However, excess Cr was unfavorable for the reaction because the active sites on the $\mathrm{V}$-based catalyst were occupied by $\mathrm{Cr}$, as shown by the curves for $\mathrm{Cr}_{0.3}-\mathrm{V}_{0.7} / \mathrm{TiO}_{2}$, $\mathrm{Cr}_{0.5}-\mathrm{V}_{0.5} / \mathrm{TiO}_{2}$, and $\mathrm{Cr}_{0.7}-\mathrm{V}_{0.3} / \mathrm{TiO}_{2}$. The $\mathrm{NO}_{x}$ conversion rate exceeded $90 \%$ at $160{ }^{\circ} \mathrm{C}$ when the $\mathrm{Cr} / \mathrm{V}$ molar ratio was $0.2: 0.8$; this catalytic activity at low temperatures is clearly better than those of the other catalysts, and the temperature window of $160-300{ }^{\circ} \mathrm{C}$ was broadened. These findings are in agreement with the $\mathrm{NH}_{3}$-TPD and $\mathrm{H}_{2}$-TPR results.

The effects of the catalyst loading on the activities of the DeNO ${ }_{x}$ catalysts were investigated; the results are shown in Fig. 7. The $\mathrm{Cr}-\mathrm{V}$ content greatly influenced the $\mathrm{NH}_{3}-\mathrm{SCR}$ activity. $\mathrm{NO}_{x}$ conversions over the catalysts decreased in the order $10 \mathrm{wt} \%>20 \mathrm{wt} \%>50 \mathrm{wt} \%>5 \mathrm{wt} \%$. As shown in Table 2 , a $5 \mathrm{wt} \%$ loading of the $\mathrm{Cr}_{0.2}-\mathrm{V}_{0.8} / \mathrm{TiO}_{2}$ catalyst contained only

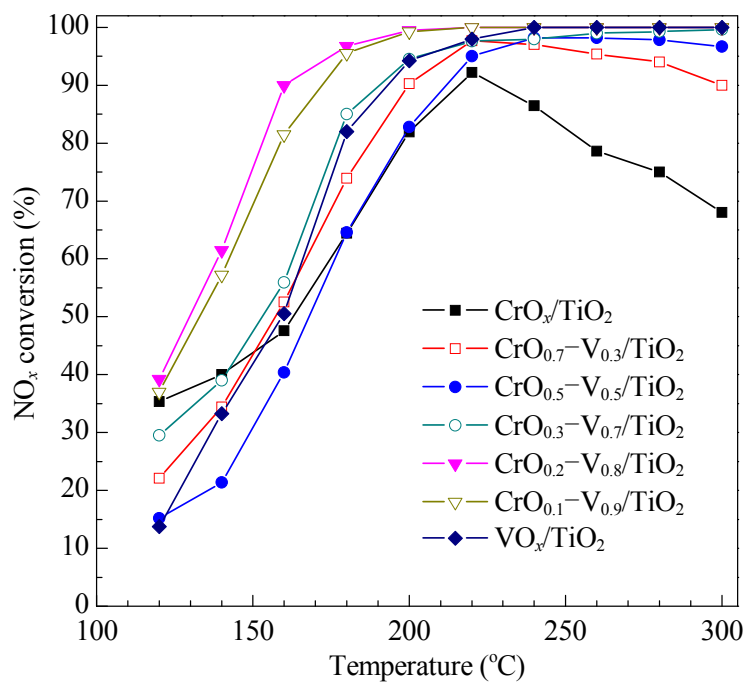

Fig. 6. $\mathrm{NO}_{x}$ conversions over catalysts with various $\mathrm{Cr} / \mathrm{V}$ molar ratios. Reaction conditions: $\mathrm{GHSV}=60000 \mathrm{~mL} /(\mathrm{h} \cdot \mathrm{g}), \varphi(\mathrm{NO})=\varphi\left(\mathrm{NH}_{3}\right)=0.05 \%$, $\varphi\left(\mathrm{O}_{2}\right)=5 \%$.

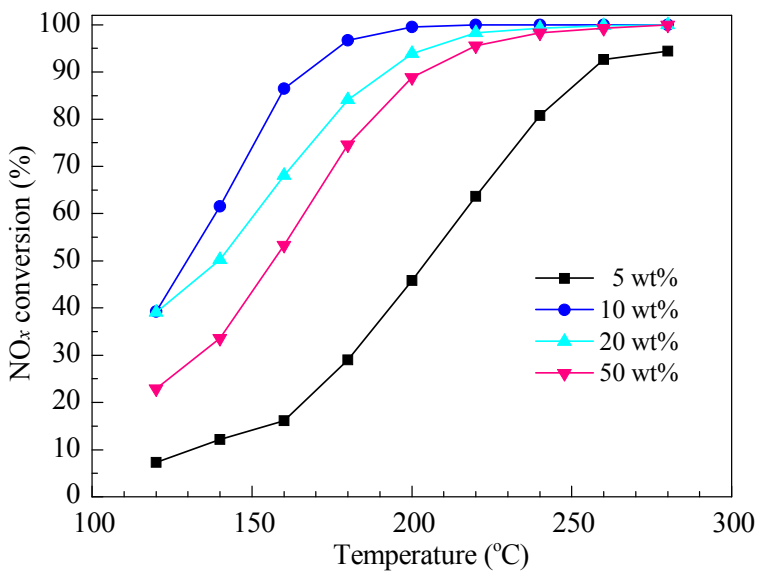

Fig. 7. Effect of active phase loading on $\mathrm{NO}_{x}$ conversion. $\varphi(\mathrm{NO})=\varphi\left(\mathrm{NH}_{3}\right)$ $=0.05 \%, \varphi\left(\mathrm{O}_{2}\right)=5 \%$.

$2.39 \% \mathrm{~V}$ on the catalyst surface. The number of active sites affects the adsorption rate, therefore the catalyst with a $5 \mathrm{wt} \%$ loading decreased the SCR reaction rate. In contrast, the catalyst containing $10 \mathrm{wt} \% \mathrm{Cr}-\mathrm{V}$ had the highest $\mathrm{V}$ content on the catalyst surface. Vanadium has a stable oxidation state of +5 ; $\mathrm{V}^{4+}$ is reduced compared with $\mathrm{V}^{5+}$ and has one extra electron, which can act as a free electron because there is no constraint on the atom, which shows high mobility and activity. It is therefore reasonable to conclude that an increased $\mathrm{V}^{4+} / \mathrm{V}^{5+}$ ratio could lead to an increase in the SCR reaction rate, as a result of the free electrons formed in non-stoichiometric $V$ [22]. The catalyst containing $10 \mathrm{wt} \% \mathrm{Cr}-\mathrm{V}$ therefore showed the highest activity and gave nearly $100 \% \mathrm{NO}_{x}$ conversion above $200{ }^{\circ} \mathrm{C}$. However, excess loading could lead to aggregation of $\mathrm{V}_{2} \mathrm{O}_{5}$ and $\mathrm{Cr}_{2} \mathrm{~V}_{4} \mathrm{O}_{13}$, cover the $\mathrm{V}$ active sites, and reduce the $\mathrm{DeNO}_{x}$ catalytic activity.

\subsection{Sulfur and water vapor resistance of catalyst}

Fig. 8 shows the resistance of the $\mathrm{Cr}_{0.2}-\mathrm{V}_{0.8} / \mathrm{TiO}_{2}$ catalyst to $\mathrm{SO}_{2}$ poisoning during SCR of $\mathrm{NO}_{x}$ with $\mathrm{NH}_{3}$. The $\mathrm{Cr}_{0.2}-\mathrm{V}_{0.8} / \mathrm{TiO}_{2}$ catalytic activity was high and $\mathrm{NO}_{x}$ conversion was higher than $75 \%$ in the absence of $\mathrm{SO}_{2}$. In $12 \mathrm{~h}$ of test with flue gas contain-

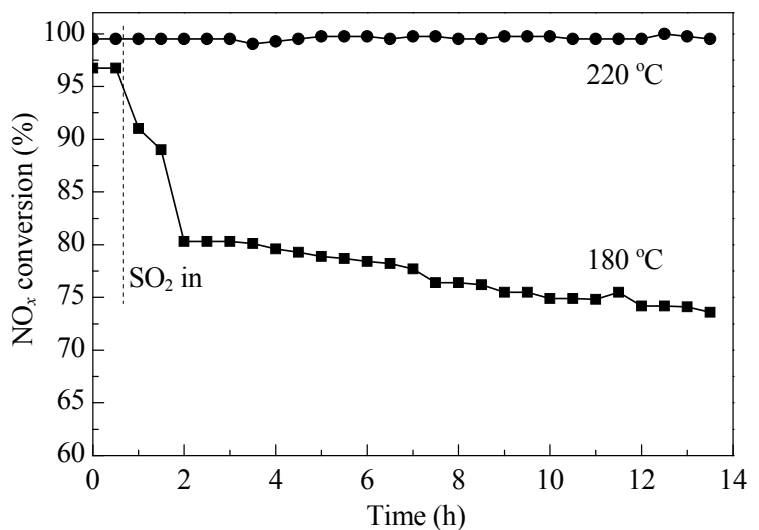

Fig. 8. Resistance to $\mathrm{SO}_{2}$ of $\mathrm{Cr}_{0.2}-\mathrm{V}_{0.8} / \mathrm{TiO}_{2}$ catalyst. Reaction conditions: $220^{\circ} \mathrm{C}$ or $180^{\circ} \mathrm{C}, \mathrm{GHSV}=60000 \mathrm{~mL} /(\mathrm{h} \cdot \mathrm{g}),\left[\mathrm{SO}_{2}\right]=100 \mathrm{ppm}$. 


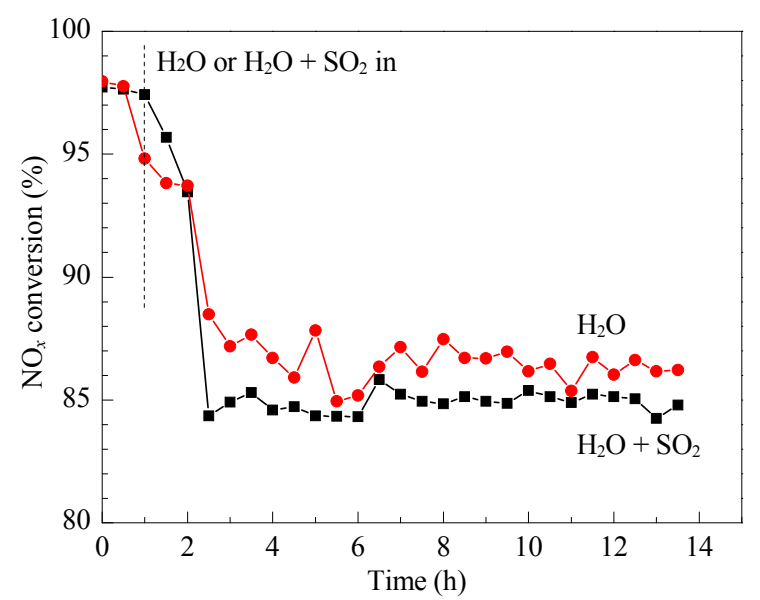

Fig. 9. Resistance to water and copresence of water $+\mathrm{SO}_{2}$ of $\mathrm{Cr}_{0.2}-\mathrm{V}_{0.8} / \mathrm{TiO}_{2}$ catalyst. Reaction conditions: $220^{\circ} \mathrm{C}$, GHSV $=60000$ $\mathrm{mL} /(\mathrm{h} \cdot \mathrm{g}),\left[\mathrm{SO}_{2}\right]=100 \mathrm{ppm}$, [water] = $10 \mathrm{vol} \%$.

ing 100 ppm SO 2 , the $\mathrm{NO}_{x}$ conversion below $220^{\circ} \mathrm{C}$ remained at about $99 \%$. Moreover, no signs of sulfur poisoning were observed. However, the introduction of $\mathrm{SO}_{2}$ slightly reduced $\mathrm{NO}_{x}$ conversion at $180^{\circ} \mathrm{C}$, because $\mathrm{SO}_{2}$ on the catalyst surface was easily adsorbed by the V-based catalyst at low temperatures, covering the active sites and ultimately inhibiting the activity.

The influence of water was tested by injecting $10 \mathrm{vol} \%$ water into the reaction. As shown in Fig. 9, the presence of water decreased the $\mathrm{NO}_{x}$ conversion by the $\mathrm{Cr}_{0.2}-\mathrm{V}_{0.8} / \mathrm{TiO}_{2}$ catalyst at $220^{\circ} \mathrm{C}$. Several authors have attributed the hindering effect of water vapor to competitive adsorption between water and $\mathrm{NH}_{3}$ [23]. The $\mathrm{Cr}_{0.2}-\mathrm{V}_{0.8} / \mathrm{TiO}_{2}$ catalyst still had sufficiently high catalytic activity to ensure that $\mathrm{NO}_{x}$ conversion was higher than $85 \%$ in the copresence of water and $\mathrm{SO}_{2}$.

\section{Conclusions}

Doping of $\mathrm{Cr}$ ions increased the amounts of weak and medium acid sites on the $\mathrm{VO}_{x} / \mathrm{TiO}_{2}$ catalyst surface, promoted the low-temperature reductive capacity of high-valence $\mathrm{V}$ ions, and increased the amount of surface oxygen on the catalyst. These factors enhanced the SCR rate. The catalyst with a $\mathrm{Cr} / \mathrm{V}$ molar ratio of 0.2:0.8 and 10\% loading had the largest amount of weak acid sites and gave the best $\mathrm{DeNO}_{x}$ performance, with $\mathrm{NO}_{x}$ conversion greater than $90 \%$ at $160-300{ }^{\circ} \mathrm{C}$. This catalyst also showed high stability in the presence of $0.01 \% \mathrm{SO}_{2}$.

\section{References}

[1] Martin J A, Yates M, Avila P, Suarez S, Blanco J. Appl Catal B, 2007, 70: 330

[2] Yang S J, Wang C Z, Li J H, Yan N Q, Ma L, Chang H Z. Appl Catal B, 2011, 110: 71

[3] Yan Z Y, Gao X, Wu J, Jiang Y, Luo Z Y, Ni M J, Cen K F. J Power Eng (间志勇, 高翔, 吴杰, 姜烨, 骆仲泱, 倪明江, 岑可法. 动力工程), 2007, 27: 282

[4] Liu C X, Chen L, Li J H, Ma L, Arandiyan H, Du Y, Xu J M, Hao J M. Environ Sci Technol, 2012, 46: 6182

[5] Tang X L, Hao J M, Xu W G, Li J H. Chin J Catal (唐晓龙, 郝吉明, 徐 文国, 李俊华. 催化学报), 2006, 27: 843

[6] Wu Z B, Jin R B, Liu Y, Wang H Q. Catal Commun, 2008, 9: 2217

[7] Yang C, Cheng H, Huang B C. Chem Ind Eng Prog (杨超, 程华, 黄碧 纯. 化工进展), 2014, 33: 907

[8] Maqbool M S, Pullur A K, Ha H P. Appl Catal B, 2014, 152-153: 28

[9] Huang Y, Tong Z Q, Wu B, Zhang J F. J Fuel Chem Technol (黄妍, 童 志权, 伍斌, 张俊丰. 燃料化学学报), 2008, 36: 616

[10] Huang H F, Zeng L, Lu H F, Zhou C H, Chen Y F. J Chem Eng Chin Univ (黄海风, 曾立, 卢晗锋, 周春何, 陈银飞. 高校化学工程学 报), 2009, 23: 871

[11] Putluru S S R, Riisager A, Fehrmann R. Catal Lett, 2009, 133: 370

[12] Zhu Z P, Liu Z Y, Liu S J, Niu H X. Appl Catal B, 2001, 30: 267

[13] Pena D A, Uphade B S, Smirniotis P G. J Catal, 2004, 221: 421

[14] Thirupathi B, Smirniotis P G. Appl Catal B, 2011, 110: 195

[15] Tong H, Luo J, Tong Z Q, Xia B, Luo H. Environ Eng Sci, 2011, 28: 711

[16] Chen Z H, Yang Q, Li H, Li X H, Wang L F, Tsang S C. J Catal, 2010, 276: 56

[17] Shan W P, Liu F D, He H, Shi X Y, Zhang C B. Appl Catal B, 2012, 115-116: 100

\section{Graphical Abstract}

Chin. J. Catal., 2015, 36: 1256-1262 doi: 10.1016/S1872-2067(15)60884-1

Performance of Cr-doped vanadia/titania catalysts for low-temperature selective catalytic reduction of $\mathrm{NO}_{x}$ with $\mathrm{NH}_{3}$

Rui Yang, Haifeng Huang *, Yijie Chen, Xixiong Zhang, Hanfeng Lu*

Zhejiang University of Technology

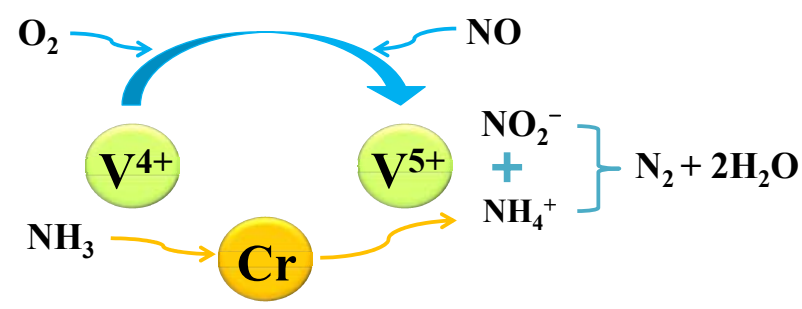

A large $\mathrm{V}^{4+} / \mathrm{V}^{5+}$ ratio could generate more free electrons, which were formed from the non-stoichiometric vanadium ions at different valence state conversion processes, and they were beneficial in improving the catalytic activity of the SCR reaction. 
[18] Li Q, Yang H S, Nie A M, Fan X Y, Zhang X B. Catal Lett, 2011, 141: 1237

[19] Nagaveni K, Hegde M S, Ravishankar N, Subbanna G N, Madras G. Langmuir, 2004, 20: 2900

[20] Zhao W, Zhong Q Pan Y X, Zhang R. Chem Eng J, 2013, 228: 815
[21] Chang H Z, Li J H, Chen X Y, Ma L, Yang S J, Schwank J W, Hao J M. Catal Commun, 2012, 27: 54

[22] Choi S H, Cho S P, Lee J Y, Hong S H, Hong S C, Hong S I.J Mol Catal A, 2009, 304: 166

[23] Busca G, Lietti L, Ramis G, Berti F. Appl Catal B, 1998, 18: 1

\title{
Cr改性钒基催化剂对 $\mathrm{NH}_{3}$ 低温选择性催化还原 $\mathrm{NO}_{x}$ 的影响
}

\author{
杨 点 ${ }^{\mathrm{a}}$, 黄海风先, ${ }^{*}$, 陈一杰 ${ }^{\mathrm{a}}$, 张细雄 ${ }^{\mathrm{a}}$, 卢晗锋 ${ }^{\mathrm{b}, \#}$

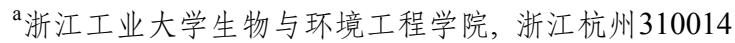

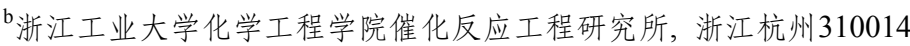

摘要: 火电厂和机动车辆等的 $\mathrm{NO}_{x}$ 排放量与日俱增, $\mathrm{NO}_{x}$ 的治理已成为环境保护的重要组成部分. 以 $\mathrm{NH}_{3}$ 作为还原剂的选择性催 化还原 $(\mathrm{SCR})$ 技术是目前消除 $\mathrm{NO}_{x}$ 最为高效的方法之一. 该反应最为典型的催化剂是 $\mathrm{V}_{2} \mathrm{O}_{5}-\mathrm{WO}_{3}\left(\mathrm{MoO}_{3}\right) / \mathrm{TiO}_{2}$, 催化活性窗口为 250-400 ${ }^{\circ} \mathrm{C}$. 国外通常将 $S C R$ 系统置于省煤器之后, 此时烟气温度在 $300{ }^{\circ} \mathrm{C}$ 上, 催化剂能保持较高的活性, 但易受到烟气中高浓 度烟尘、 $\mathrm{SO}_{2}$ 和碱金属等的影响, 寿命相对较短. 此外, 高温工艺中副产物硫酸铵的堵塞也是一个不可忽视的问题. 因此, 将 SCR 脱硝装置设在脱硫除尘之后成为一种优选技术之一, 但烟气温度会降至 $250^{\circ} \mathrm{C}$ 以下, 而常规的钒基催化剂不能满足低温活性要求. 通过添加助剂或改变载体可改善钒基催化剂的低温活性, 同时保持其高效的抗硫能力.

本文以 $\mathrm{Cr}$ 和 $\mathrm{V}$ 为活性组分, $\mathrm{TiO}_{2}$ 为载体, 采用浸渍法制备了铬钒钛 $\left(\mathrm{Cr}-\mathrm{VO}_{x} / \mathrm{TiO}_{2}\right)$ 系列催化剂, 考察了它们的低温脱硝活性和 抗水抗硫性, 并通过 $\mathrm{N}_{2}$ 吸附-脱附、 $\mathrm{X}$ 射线衍射、 $\mathrm{NH}_{3}$ 程序升温脱附 $\left(\mathrm{NH}_{3}-\mathrm{TPD}\right) 、 \mathrm{H}_{2}$ 程序升温还原 $\left(\mathrm{H}_{2}-\mathrm{TPR}\right)$ 和 $\mathrm{X}$ 射线光电子能谱等 手段对催化剂进行了表征, 分析了 $\mathrm{Cr}-\mathrm{V}$ 催化剂的作用机制.

结果显示, 当 $n(\mathrm{Cr}): n(\mathrm{~V})$ 为 $0.2: 0.8$, 活性组分负载量为 $10 \mathrm{wt} \%$ 时, $\mathrm{Cr}-\mathrm{VO}_{x} / \mathrm{TiO}_{2}$ 催化剂表现出最佳的低温催化活性; 当反应温度 为 $160^{\circ} \mathrm{C}$ 时, $\mathrm{NO}_{x}$ 转化率达到 $90 \%$ 以上, 明显优于其他催化剂, 同时活性窗口 $\left(160-300{ }^{\circ} \mathrm{C}\right)$ 得到拓宽. $\mathrm{NH}_{3}-\mathrm{TPD}$ 结果表明, $\mathrm{VO}_{x} / \mathrm{TiO}_{2}$ 催化剂表面呈中弱酸性, 随着 $\mathrm{Cr}$ 的添加, 钒基催化剂的 $\mathrm{NH}_{3}$ 脱附峰向高温拓宽, 说明其表面强酸量有所增加, $\mathrm{Cr}_{0.2}-\mathrm{V}_{0.8} / \mathrm{TiO}_{2}$ 在 160-300 ${ }^{\circ} \mathrm{C}$ 范围内均出现了 $\mathrm{NH}_{3}$ 的脱附峰, 此时催化剂表面弱酸量最大. 当 $n(\mathrm{Cr}): n(\mathrm{~V})$ 大于 $0.2: 0.8$ 时, 催化剂表面出现强酸位, 这种 强酸位不利于 $\mathrm{NH}_{3}$ 脱附, 从而不利于 $\mathrm{SCR}$ 反应的进行. 因此适量 $\mathrm{Cr}$ 的添加有助于提高钒基催化剂表面弱酸及中性酸量. $\mathrm{H}_{2}$-TPR结 果发现, 助剂 $\mathrm{Cr}$ 的添加使得催化剂表面氧量增加, 这可能是由于 $\mathrm{Cr}$ 的添加形成了较多的氧空穴和未饱和的化学键. 催化剂表面化 学吸附氧是氧化还原反应最活跃的氧物种, 在 $\mathrm{SCR}$ 反应中, 表面氧可作为 $\mathrm{NO}$ 的吸附介质参与到催化剂表面反应中, 可有效提高 SCR 反应速率. 通过考察活性组分负载量对催化剂活性的影响, 发现不同负载量催化剂的催化活性依次为 $10 \mathrm{wt} \%>20 \mathrm{wt} \%>$ $50 \mathrm{wt} \%>5 \mathrm{wt} \%$. XPS分析发现, 当负载量为 $10 \mathrm{wt} \%$ 时, 催化剂表面非计量的钒离子和化学性质活跃的自由电子最多, 因此表现出 最佳的SCR 活性; 当负载量过高时, 大量氧化物堆积烧结形成 $\mathrm{V}_{2} \mathrm{O}_{5}$ 和 $\mathrm{Cr}_{2} \mathrm{~V}_{4} \mathrm{O}_{13}$, 覆盖了钒离子活性位点, 降低了催化剂脱硝效率.

催化剂在 $220^{\circ} \mathrm{C}$ 表现出良好的抗硫性, 在通入 $100 \mathrm{ppm} \mathrm{SO}_{2} 12 \mathrm{~h}$ 后 $\mathrm{NO}_{x}$ 的转化率仍可达 $99 \%$ 以上, 并未出现硫中毒现象. 同时 该催化剂也表现出较好的抗水性, 在通入 $10 \mathrm{vol} \%$ 水蒸气 $12 \mathrm{~h}$ 后, $\mathrm{NO}_{x}$ 转化率仍能达 $85 \%$ 以上.

关键词: 低温; 选择性催化还原; 氨; 铬钒钛催化剂; 烟气脱硝; 抗硫性；铬掺杂

收稿日期: 2015-03-04. 接受日期: 2015-05-06. 出版日期: 2015-08-20.

*通讯联系人. 电话/传真: (0571)88320385; 电子信箱: hhf66@zjut.edu.cn

\#通讯联系人. 电话/传真: (0571)88320767; 电子信箱: luhf@zjut.edu.cn

基金来源：国家自然科学基金(21107096); 浙江省自然科学基金(LY14E080008); 浙江省科学技术委员会(2013C03021).

本文的英文电子版由Elsevier出版社在ScienceDirect上出版(http://www.sciencedirect.com/science/journal/18722067). 